\title{
Colchicine and oryzalin effects on tetraploid induction and leaf anatomy of Solanum commersonii ssp.
}

\author{
Colchicina e orizalina na indução de tetraploides e na \\ anatomia foliar de Solanum commersonii ssp.
}

\author{
Lívia Gracielle Oliveira Tomé ${ }^{1}$ Adriano Bortolotti da Silva ${ }^{I^{*}}$ \\ Cesar Augusto Brasil Pereira Pinto ${ }^{\text {II }}$ Lisete Chamma Davide ${ }^{\text {II }}$ \\ Dalvana Sousa Pereira ${ }^{I I}$ Carlos Roberto de Carvalho ${ }^{I}$
}

\section{ABSTRACT}

The aim of the present study was to evaluate the effect of the colchicine and oryzalin anti-mitotic substances on the induction of tetraploid plants and foliar anatomy of two diploids clones of Solanum commersonii ssp. Nodal segments of Solanum commersonii subsp. commersonii Dun. and Solanum commersonii subsp. malmeanum Bitt. were treated with colchicine $(3.5,5.0$, and $6.5 \mathrm{mM} ; 72 \mathrm{~h})$ or oryzalin $(10,30$, and $50 \mu \mathrm{M} ; 24 \mathrm{~h})$. After the treatment with anti-mitotic substances, nodal segments were inoculated in the MS culture medium and cultivated in vitro (60 days). After in vitro cultivation, the plants were transferred to vases with the substrate Plantmax ${ }^{\mathbb{B}}$ and kept in the greenhouse 45 days). Plant ploidy level was assessed by flow cytometry and leaf anatomy was assessed by anatomic cuts. An increase was observed in the polar and equatorial diameter of stomata ("gigas effect") of the Solanum commersonii subsp. commersonii (SCC) and Solanum commersonii subsp. malmeanum (SCM) clones, which was due to the use of the anti-mitotic substances. Treatments with colchicine $(6.5 \mathrm{mM} ; 72 \mathrm{~h})$ and oryzalin $(50 \mu \mathrm{M} ; 24 \mathrm{~h})$ caused death of the SCC plants cultured in vitro. In the others treatments of the SCC clone, the use of oryzalin and colchicine caused production of chimeric plants. The treatment of nodal segments of SCM with oryzalin $(10-50 \mu M ; 24 h)$ was effective on induction of tetraploid plants, which can be employed in genetic breeding programs in crossbreeding with cultured potato.

Key words: potato, crop breeding, flow citometry, foliar anatomy.

RESUMO

$O$ objetivo deste estudo foi avaliar o efeito das substâncias antimitóticas colchicina e orizalina na indução de plantas tetraploides e na anatomia foliar de dois clones diploides de Solanum commersonii ssp. Segmentos nodais de Solanum commersonii subsp. commersonii Dun. e Solanum commersonii subsp. malmeanum Bitt. foram tratados com colchicina (3,5,

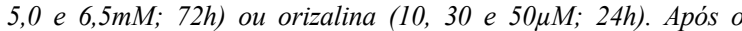
tratamento com as substâncias antimitóticas, os segmentos nodais foram inoculados em meio de cultura MS e cultivados in vitro (60 dias). Após o cultivo in vitro, as plantas foram transferidas para vasos contendo o substrato Plantmax ${ }^{\circledR}$ e mantidas em casa de vegetação (45 dias). O nivel de ploidia das plantas foi avaliado por citometria de fluxo e a anatomia foliar foi avaliada através de cortes anatomicos. Foi observado um aumento no diâmetro equatorial e polar dos estômatos ("efeito gigas") dos clones de Solanum commersonii subsp. commersonii (SCC) e Solanum commersonii subsp. malmeanum (SCM), que foi produzido pelo uso de substâncias antimitóticas. O tratamento com colchicina $(6,5 \mathrm{mM}$; $72 h)$ e orizalina $(50 \mu M$; 24h) causou morte nas plantas de SCC cultivadas in vitro. Nos demais tratamentos do clone de SCC, o uso de orizalina ou colchicina causou a produção de plantas quiméricas. O emprego de orizalina $(10-50 \mu \mathrm{M} ; 24 \mathrm{~h})$, nos segmentos nodais de SCM, resultou na obtenção de plantas tetraploides consistentes, as quais podem ser usadas nos programas para melhoramento genético em cruzamentos com a batata cultivada.

Palavras-chave: batata, melhoramento genético, citometria de fluxo, anatomia foliar.

\section{INTRODUCTION}

Potato (Solanum tuberosum subsp. tuberosum L.) is an important crop, being one of the four most consumed foods in the world, along with corn, rice, and wheat (FAO, 2014). Although potato is heavily investigated, its cultivation in the tropics had problems such as viral and bacterial diseases

\footnotetext{
IDepartamento de Biologia, Universidade Federal de Viçosa (UFV), Viçosa, MG, Brasil.

IICurso de Agronomia, Universidade José do Rosário Vellano (UNIFENAS), Rod. MG 39, Km 0, 37130-000, Alfenas, MG, Brasil. E-mail: adriano.silva@unifenas.br. "Corresponding author.

IIIDepartamento de Biologia, Universidade Federal de Lavras (UFLA), Lavras, MG, Brasil. 
and a narrow genetic base. These factors limit its production and hamper the crop genetic improvement (CARUSO et al., 2008).

In the programs for genetic improvement of potato, wild species and the commercial cultivar were crossed in order to both introduce alleles of interest and increase the genetic basis, aiming to incorporate in cultivars of genetic characteristics such as resistance to pests and diseases, as well as tolerance to the abiotic stress (CARUSO et al., 2008). Solanum commersonii ssp. is a highlighted wild species, as it has alleles for resistance to the bacterial wilt (Ralstonia solanacearum) and soft rot caused by Erwinia carotovora (CARPUTO et al., 1997). However, in crosses between the tetraploid $(4 \mathrm{x})$ commercial cultivars and diploid $(2 \mathrm{x})$ wild species, the seeds are abortive in their early development due to endosperm incompatibilities (HANNEMAN, 1999).

In the potato crop, crosses between related species, with different endosperm balance number (EBN) have been unsuccessful. Two evolutionarily closely related species, with the same ploidy but different $\mathrm{EBN}$, are incompatible due to reproductive isolation via EBN (CARPUTO et al., 1997). Species with $2 \mathrm{x}(2 \mathrm{EBN})$ ploidy can only cross with other species that have $2 \mathrm{EBN}$, i.e., $2 \mathrm{x}(2 \mathrm{EBN})$ or $4 \mathrm{x}(2 \mathrm{EBN})$ species. To overcome this incompatibility barrier and simultaneously transfer genes of agronomic interest from the $(2 \mathrm{n}=2 \mathrm{x}=24 ; 1 \mathrm{EBN})$ wild species to the Solanum tuberosum subsp. tuberosum $(2 \mathrm{n}=4 \mathrm{x}=$ 48; 4EBN) cultivars, some researchers have doubled the chromosomes from the Solanum spp. wild species (CARPUTO et al., 1997; HANNEMAN, 1999).

Duplication of chromosomes from potato wild species can be obtained by treatment of their somatic tissues (leaves, stem segments, meristems, and mini tubercles) (CHAUVIN et al., 2003; QUESENBERRY et al., 2010) with antimitotic substances such as colchicine and oryzalin (HANNEMAN, 1999). This treatment allows to obtain tetraploid plants that can be used in genetic improvement programs in crosses with the cultivated subspecies.

The objective of this study was to analyze the effect of colchicine and oryzalin treatment on the tetraploid plants and leaf anatomy in the Solanum commersonii subsp. commersonii and Solanum commersonii subsp. malmeanum diploid clones.

\section{MATERIALS AND METHODS}

In vitro culture

The Solanum commersonii subsp. commersonii Dunal and Solanum commersonii subsp. malmeanum Bitter diploid clones were obtained by meristem culture and cultured in vitro through micropropagation techniques. Nodal segments (about 1.5-cm length) of these clones were used to design the experiment.

The treatments included different concentrations of colchicine $(3.5,5.0$, and $6.5 \mathrm{mM}$; $72 \mathrm{~h})$ or oryzalin $(10,30$, and $50 \mu \mathrm{M} ; 24 \mathrm{~h})$. In addition to these treatments, a control treatment was performed with plants that were not exposed to the antimitotic substances. Nodal segments were immersed in a previously filtered $\left(0.22 \mu \mathrm{m}\right.$; Millex $\left.{ }^{\circledR}\right)$ antimitotic solution $(40 \mathrm{~mL})$. After an exposure period ( 24 or $72 \mathrm{~h}$ ), these segments were inoculated into a culture medium (total: 12 explants per treatment). The colchicine and oryzalin doses and the exposure times used in this study were adapted from reports by BARANDALLA et al. (2006).

The culture medium comprised salts as described by MURASHIGE \& SKOOG (1962), added with sucrose $\left(30 \mathrm{~g} \mathrm{~L}^{-1}\right)$, solidified with agar $(7 \mathrm{~g}$ $\left.\mathrm{L}^{-1}\right)$, and the $\mathrm{pH}$ value was adjusted $(5.7 \pm 1.0)$ prior to autoclaving $\left(121^{\circ} \mathrm{C} ; 20 \mathrm{~min}\right)$. The plants were incubated in a growth chamber (light photoperiod: 16 $\mathrm{h}$; temperature: $24 \pm 1^{\circ} \mathrm{C}$; light intensity: $36 \mu \mathrm{mol} \mathrm{m} \mathrm{m}^{-2}$ $\mathrm{s}^{-1}$; period: 60 days).

Due to the low differentiation of axillary buds per explant, three plants per treatment of in vitro culture were selected for acclimatization. All plants were transferred to pots (\# 5) containing pine bark $\left(\right.$ Plantmax $\left.^{\circledR}\right)$ as a substrate and kept in a greenhouse (PADFAN model) covered with 50\% Sombrite ${ }^{\circledR}$ (night temperature: $15 \pm 2^{\circ} \mathrm{C}$; day temperature: $28 \pm 2^{\circ} \mathrm{C}$; and misting system with relative humidity $(\mathrm{RH})$ control adjusted to $75 \%$ ). After 45 days in a greenhouse, the plant ploidy level was assessed by flow cytometry.

Flow cytometry evaluation

Three leaf fragments per plant were removed, one fragment per leaf was sampled, and three plants per treatment were evaluated. The leaf fragments $\left(20 \mathrm{~mm}^{2}\right)$ were macerated in the Otto-I lysis buffer $(500 \mu \mathrm{L} ; 0.1 \mathrm{M}$ citric acid; $0.5 \%$, v/v, Tween 20; $\mathrm{pH} 2.3$ ), and the suspension was filtered (membrane pore diameter: $40 \mu \mathrm{m}$ ) and transferred to clean tubes, which were then centrifuged $(250 \mathrm{~g})$. After centrifugation, the pellet containing the nuclei was collected and homogenized in the Otto-I buffer $(100 \mu \mathrm{L})$, stained $(15 \mathrm{~min}$; in the dark) with

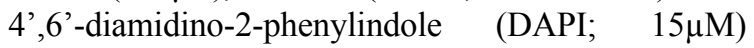
solution in the Otto-II phosphate $\left(\mathrm{Na}_{2} \mathrm{HPO}_{4} ; 400 \mathrm{mM}\right)$ buffer. The Solanum esculentum species was used as a standard $(2 \mathrm{C}=1.96 \mathrm{pg})$ to calibrate the flow cytometer. 
The nuclei suspension was analyzed in the Partec (model PAS II/III; Partec GmbH; Münster, Germany) flow cytometer. A high-pressure mercury lamp (HBO-100W) and filters (KG 1, BG 38, and XL 435) were used for analysis of the DAPI-stained nuclei. About 10 thousand nuclei per plant sample were analyzed by the FLOWMAX ${ }^{\circledR}$ (Partec) software.

\section{Anatomic evaluation}

The leaves used in the anatomical studies were collected and maintained in alcohol $(70 \%$ GL). The leaf sections were performed free hand. The paradermal cuts were made in the abaxial face (middle region) of leaves and stained with $1 \%$ safranin hydroalcoholic solution. The stomatal frequency was obtained using a light camera (Olympus microscope CBB), according to the ARAGÓN et al. (2010) technique. The polar and equatorial diameters of stomata were determined using an ocular micrometer. Three leaves per plant were collected and three plants per treatment were evaluated in a total of nine paradermal cuts, which were used to obtain data for stomatal frequency and stomatal polar and equatorial diameters.

\section{Statistical analysis}

Two experiments, one for each Solanum commersonii subspecies under study were performed. In both cases, the completely randomized design (CRD), comprised seven treatments (control, 3 oryzalin concentrations, and 3 colchicine concentrations) with three replications. The leaf anatomy data were submitted to analysis of variance (ANOVA) using the statistical SISVAR software (FERREIRA, 2011), and the averages were compared by the Scott and Knott test (5\% probability).

\section{RESULTS AND DISCUSSION}

\section{Chromosome duplication}

The DNA content analysis by flow cytometry resulted in histograms with a clear resolution necessary to identify that all control plants were diploid and those treated with the antimitotic substances were diploid, triploid, tetraploid, hexaploid, and mixoploids (Figure 1).

Cell suspensions of three Solanum commersonii subsp. commersonii (SCC 07) plants were treated with colchicine $(3.5 \mathrm{mM})$ and oryzalin $(30 \mu \mathrm{M})$ and produced $2 \mathrm{x} / 4 \mathrm{x}$ and $4 \mathrm{x} / 8 \mathrm{x}$ mixoploids, respectively. Treatments with colchicine $(6.5 \mathrm{mM})$ and oryzalin $(50 \mu \mathrm{M})$ caused death of SCC 07 clone plant material in the in vitro cultivation phase.
Explants exposed to oryzalin $(10 \mu \mathrm{M})$ produced hexaploid plants (Table 1). It mentioned that the three plants evaluated after each treatment showed the same results regarding ploidy level.

The Solanum commersonii subsp. malmeanum (SCM 60) clones treated with oryzalin $(10-50 \mu \mathrm{M})$ were duplicated, generating tetraploid plants. Triploid plants were observed to occur after treatment with colchicine $(5 \mathrm{mM})$. Conversely, plants treated with colchicine $(3.5$ and $6.5 \mathrm{mM})$ remained diploid (Table 1). Three repetitions or plants evaluated within each treatment showed the same result in the flow cytometry analysis.

In three treatments that promoted production of tetraploid plants in the SCM 60 clone (Table 1), all plants exhibited stability as showed in the flow cytometry analysis. In this case, the existence of mixoploidy in the tetraploid plants was discarded because three leaf samples (from different positions, in each of the obtained treated plants) were selected, and these samples were evaluated separately. This result as observed in the SCM 60 clone, in the presence of oryzalin (Table 1), and might be explained by the in vitro culture of nodal segments with subsequent regeneration of axillary buds. The bud bursts originated from one or a few cells of the meristematic tissue results in a low frequency of chimeric plant regeneration since the exposure time as well as type and concentration of the antimitotic substance used for chromosome duplication was previously adjusted (LATADO et al., 2007). In addition, ALLUM et al. (2007) reported that oryzalin diffuses better into the meristematic tissue through the cut (which was made in the explant during micropropagation) than through the epidermis or cuticle (which seems to prevent the substance from entering). This may have favored polyploidization via tissue culture.

In treatments performed with the SCC 07 clone in the presence of colchicine $(3.5 \mathrm{mM})$ and oryzalin $(30 \mu \mathrm{M})$, occurrence of mixoploid(Table 1 and Figures $1 \mathrm{~B}$ and 1D), hexaploid, and no stable tetraploid (Table 1) plants was observed. This may be due to the interaction between genotype and antimitotic substances used. The choice of the antimitotic substance and adjustments in its concentration and exposure time are limiting factors in polyploidization induction. Some studies have reported that there is evidence of a strong interaction between the antimitotic treatment and potato genotype (BARANDALLA et al., 2007; CHAUVIN et al., 2003).

Interaction between antimitotic substance and SCM 60 clone occurred in a productive way, as oryzalin $(10-50 \mu \mathrm{M})$ promoted generation of tetraploid plants. As for e SCC 07 clone, stable tetraploid plants were not produced with the use of different colchicine 


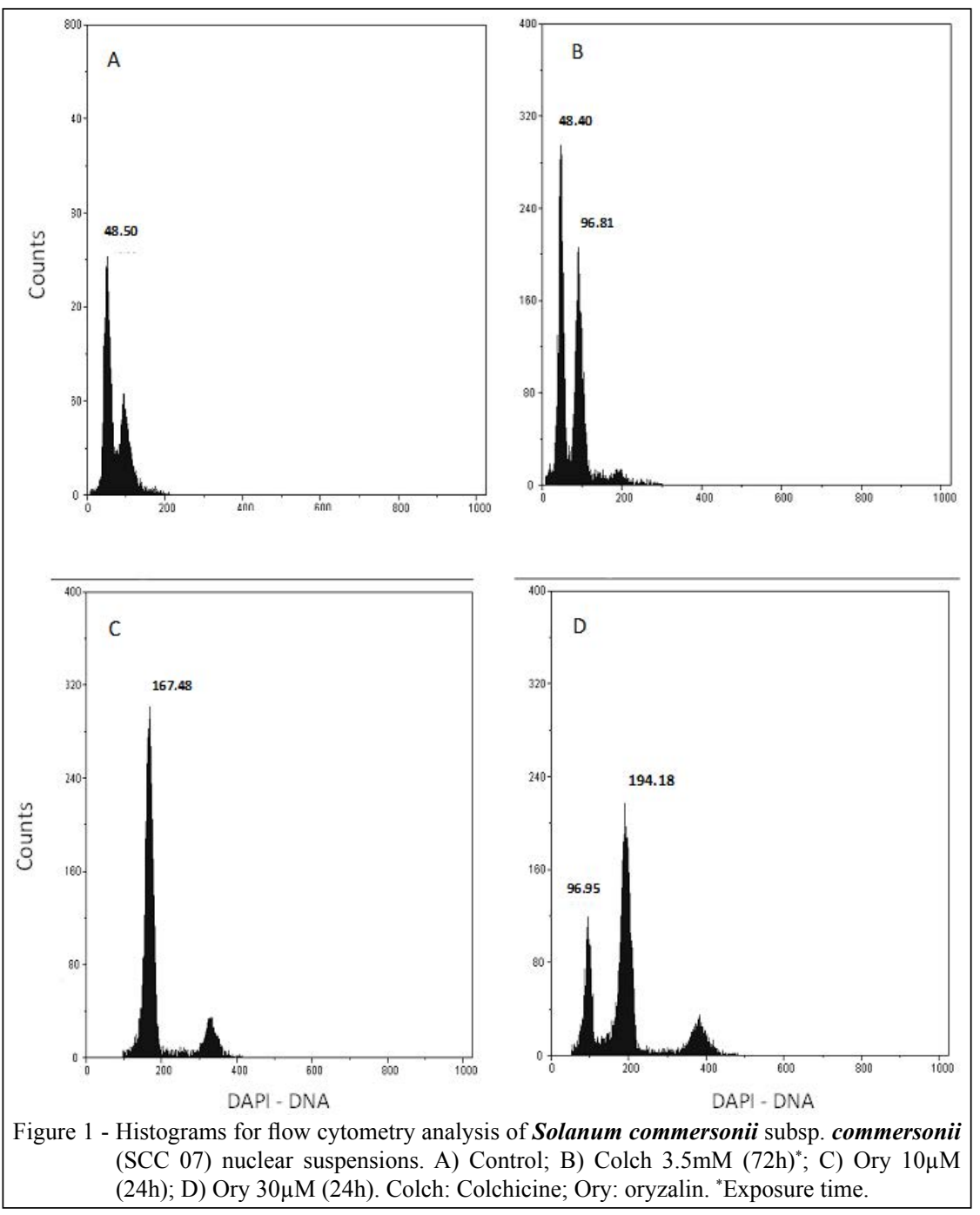

and oryzalin concentrations (Table 1). With regard to obtaining tetraploid plants in potato genotypes, the use of oryzalin was more effective than colchicine. However, the success obtained with the use of oryzalin depends on the genotype (BARANDALLA et al., 2007; CHAUVIN et al., 2003). The use of oryzalin (10 $\mu \mathrm{M}$; exposure: $24 \mathrm{~h})$ provided the best chromosome duplication results only for the L 37 potato genotype (CHAUVIN et al., 2003). The results obtained in the present study agree with those of CHAUVIN et al., (2003) for the production of tetraploid plants with the use of oryzalin (Table 1).

Occurrence of tetraploid plants with oryzalin but not colchicine (Table 1), may be related to the differences between the chemical structures and antimitotic properties of these substances. Oryzalin and amiprophos-methyl act more efficiently in microtubule depolymerization in potato cells, allowing to obtain a higher frequency of tetraploid cells (CHAUVIN et al. 2003). This may have favored the occurrence of tetraploidy in the SCM 60 genotype (Table 1). Oryzalin has shown to be effective in the chromosome duplication in roses (ALLUM et al., 2007), and other fruit and ornamental plants (DHOOGHE et al., 2011).

The use of tetraploid plants, which was obtained by induced polyploidization in wild species of the genus Solanum, has been used as a means to transfer genes of agronomic interest from these species to cultivated potato (DHOOGHE et al., 2011). Obtaining tetraploid plants from SCM 60 clones (Table 1) is an important step, so that these plants can be employed in genetic breeding programs.

Leaf anatomy

Plant leaves from oryzalin $(30 \mu \mathrm{M})$ treated SCC 07 clones showed a lower stomatal density relative to other treatments. Control plants

Ciência Rural, v.46, n.11, nov, 2016. 
Table 1 - Flow cytometry data for nuclear suspensions of leaves from Solanum commersonii subsp. commersonii (SCC 07) and Solanum commersonii subsp. malmeanum (SCM 60) clones stained with the DAPI fluorochrome.

\begin{tabular}{|c|c|c|c|}
\hline \multirow{2}{*}{ Treatments } & Readings (G1) & Indices $^{(1)}$ & Ploidy \\
\hline & ------ & CC 07 clone & -------- \\
\hline Control & 48.50 & 1.00 & $2 x$ \\
\hline Colch $3.5 \mathrm{mM}(72 \mathrm{~h})^{*}$ & $48.40 / 96.81$ & 1.99 & $2 x / 4 x$ \\
\hline Colch 5.0mM (72h) & 48.87 & 1.00 & $2 x$ \\
\hline Ory $10 \mu \mathrm{M}(24 \mathrm{~h})^{*}$ & 167.48 & 3.45 & $6 x$ \\
\hline Ory $30 \mu \mathrm{M}(24 \mathrm{~h})$ & $96.95 / 194.18$ & $1.99 / 4.00$ & $4 x / 8 x$ \\
\hline Control & 51.08 & 1.00 & $2 x$ \\
\hline Colch $3.5 \mathrm{mM}(72 \mathrm{~h})^{*}$ & 42.20 & 0.82 & $2 \mathrm{x}$ \\
\hline Colch 5.0mM (72h) & 75.98 & 1.48 & $3 x$ \\
\hline Colch 6.5mM (72h) & 51.91 & 1.00 & $2 \mathrm{x}$ \\
\hline Ory $10 \mu \mathrm{M}(24 \mathrm{~h})^{*}$ & 101.94 & 1.99 & $4 x$ \\
\hline Ory $30 \mu \mathrm{M}(24 \mathrm{~h})$ & 102.04 & 1.99 & $4 x$ \\
\hline Ory $50 \mu \mathrm{M}(24 \mathrm{~h})$ & 103.12 & 2.00 & $4 x$ \\
\hline
\end{tabular}

Index 1 was attributed to the control (diploid standard plant); ${ }^{*}$ Exposure time; Ory: Oryzalin; Colch: Colchicine.

showed 148.74 stomata $\mathrm{mm}^{-2}$ (Figure 2A). In plant leaves from the SCM 60 clone, which were treated with colchicine $(5.0$ and $6.5 \mathrm{mM})$ and different doses of oryzalin, the stomatal density was lower than that observed in the control plant leaves (127.28 stomata $\mathrm{mm}^{-2}$ ) (Figure 2B). The stomatal density may change with polyploidization, as polyploid plants generally exhibit a lower stomatal density (HODGSON et al., 2010).

Increase observed in one or both (equatorial and polar) stomatal diameters occurred in most treatments with antimitotic substances in the SCC 07 and $60 \mathrm{SCM}$ clones (Figure $2 \mathrm{AB}$ and Figure 3) compared to control plants, except in treatments with



Ciência Rural, v.46, n.11, nov, 2016. 



Figure 3 - Photomicrographs of paradermal sections of potato leaves. A) Control treatment of Solanum commersonii subsp. commersonii

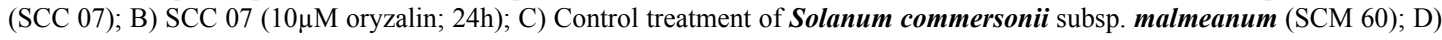
SCM $60(10 \mu \mathrm{M}$ oryzalin; $24 \mathrm{~h})$. Stomata classified as anomocitic type.

colchicine (3.5 and $5.0 \mathrm{mM})$ in the SCM 60 clone (Figure 2B). Larger stomata can be a good indication of polyploidization induction, being observed consistently in the SCM 60 tetraploid plants obtained by treatment with oryzalin $(10,30$, and $50 \mu \mathrm{M})$ (Figure $2 \mathrm{~B}$, Figure $3 \mathrm{CD}$ and Table 1). The "gigas effect" can explain this enlarging behavior in the stomatal size due to the treatment with antimitotic substances. The "gigas effect" is analyzed by observing the morphological and anatomical characteristics, in which the plant organs and cells exhibit a volume increase proportional to the increase in DNA amount. Polyploidized plants tend to have larger stomata in relation to those of non-duplicated genomes (HODGSON et al., 2010; QUESENBERRY et al., 2010), and they can serve as an indication of increase in the DNA amount in plant cells.

\section{CONCLUSION}

In vitro culture of nodal segments from Solanum commersonii subsp. malmeanum treated with oryzalin allows obtaining tetraploid plants, enabling allele transfer from these plants to the cultivated potato ones.

Use of colchicine or oryzalin at doses tested in Solanum commersonii subsp. commersonii is not effective in producing tetraploid plants. In the leaf anatomy, increase in the stomatal size is related to the "gigas effect" due to the use of antimitotic substances.

\section{REFERENCES}

ALLUM, J.F. et al. Chromosome doubling in Rose rugosa Thumb. hibrid by exposure in vitro nodes to otyzalin: the effects of node length, oryzalin concentration and exposure time. Plant Cell Reports, v.20, p.1977-1984, Nov. 2007. Available from: <http:// link.springer.com/article/10.1007/s00299-007-0411-y>. Accessed: Nov. 20, 2015. doi: 10.1007/s00299-007-0411-y.

ARAGÓN, C. et al. Ex vitro acclimatization of plantain plantlets micropropagated in temporary immersion bioreactor. Biologia Plantarum, v.54, p.237-244, Mar. 2010. Available from: <http:// link.springer.com/article/10.1007\%2Fs10535-010-0042-y\#/page-2>. Accessed: Jun. 06, 2016. doi: 10.1007/s10535-010-0042-y.

Ciência Rural, v.46, n.11, nov, 2016. 
BARANDALLA, L. et al. Oryzalin treatment of potato diploids yields. Tetraploid and chimeric plants from which euploids could be derived by callus induction. Potato Research, v.49, p.143-154, Jan. 2007. Available from: <http://link.springer.com/article/10.100 7\%2Fs11540-006-9014-1>. Accessed: Feb. 15, 2015. doi: 10.1007/ s11540-006-9014-1.

CARPUTO, D. et al. Endosperm balance number manipulation for direct in vivo germplasm introgression to potato from a sexually isolated relative (Solanum commersonii Dun.). Proceedings of National Academy of Science, v.94, n.22, p.12013-12017, Oct. 1997.

CARUSO, I. et al. Breeding potential of Solanum tuberosum-S. commersonii pentaploid hybrids: fertility studies and tuber evaluation. Euphytica, v.164, p.357-363, Nov. 2008. Available from: <http:/ www.pbglab.it/attachments/110_Caruso\%20et\%20al.\%202008.pdf $>$. Accessed: Mar. 10, 2015. doi: 10.1007/s10681-008-9673-x.

CHAUVIN, J.E. et al. Chromosome doubling of 2XSolanum species by oryzalin: method development and comparison with spontaneous chromosome doubling in vitro. Plant Cell, Tissue Organ and Culture, v.73, p.65-73, Apr. 2003. Available from: $<$ http://hortsci. ashspublications.org/content/42/6/1326.full.pdf + html $>$. Accessed: Apr. 22, 2015. doi: 10.1023/A:1022663816052.

DHOOGHE, M. et al. Mitotic chromosome doubling of plant tissue in vitro. Plant Cell Tissue and Organ Culture, v.104, p.359-373, Nov. 2011. Available from: < http://link.springer.com/ar ticle/10.1007\%2Fs11240-010-9786-5>. Accessed: Nov. 20, 2015. doi: $10.1007 / / \mathrm{s} 11240-010-9786-5$.

FERREIRA, D.F. SISVAR: a computer statistical system. Ciência e Agrotecnologia, v.35, n.6, p.1039-1042, Nov./Dec. 2011. Available from: <http://www.scielo.br/pdf/cagro/v35n6/a01v35n6.pdf $>$. Accessed: Jan. 18, 2015. doi: 10.1590/S1413-70542011000600001.

FAO. Production year book 2014. Food and Agriculture Organization of the United Nations, Rome, 2014. Online. Available from: <http:// www.fao.org/3/a-i3590e.pdf>. Accessed: Mar. 10, 2015.

HANNEMANN, R.E. The reproductive biology of the potato and its implication for breeding. Potato Research, v.42, n.1, p.283312, Jun. 1999. Suppl. Available from: <http://link.springer.com/ article/10.1007\%2FBF02357859>. Accessed: Feb. 15, 2015. doi:10.1007/BF02357859.

HODGSON, J.G. et al. Stomatal vs. genome size in angiosperms: the somatic tail wagging the genomic dog? Annals of Botany, v.105, n.4, p.573-584, Apr. 2010. Available from: <http://www. ncbi.nlm.nih.gov/pubmed/20375204>. Accessed: Feb. 15, 2015. doi: $10.1093 / \mathrm{aob} / \mathrm{mcq} 011$.

LATADO, R.R. et al. Citrus autotetraploid plants obtained by in vitro treatment with colchicine. Pesquisa Agropecuária Brasileira, v.42, n.10, p.1429-1435, Oct. 2007. Available from: $<$ http://www.scielo.br/pdf/pab/v42n10/a09v4210.pdf $>$. Accessed: June 15, 2014. doi: org/10.1590/S0100-204X2007001000009.

MURASHIGE, T.; SKOOG, F. A revised medium for rapid growth and bioassays with tobacco tissue cultures. Physiologia Plantarum, v.15, p.473-497, Feb. 1962.

QUESENBERRY, K.H. et al. Doubling the chromosome number of bahiagrass via tissue culture. Euphytica, v.17, n.1, p.43-50, 2010. Available from: $<$ http://link.springer.com/article/10.1007/s10681-0100165-4>. Accessed: July 20, 2014. doi: 10.1007/s10681-010-0165-4. 